\title{
EFFECT OF EVIDENCE BASED LIFESTYLE GUIDELINES ON SELF-EFFICACY AMONG HYPERTENSION PATIENTS
}

\author{
Shaimaa Ali Elwesif ${ }^{1}$, Gehad Mohammed Abu- Elmatty², Reda Ibrahim El-Mowafy3, \\ Magda Ali Mohamed ${ }^{4}$ \\ B.Sc. Nursing ${ }^{1}$, Professor of family and community health nursing department ${ }^{2}$, Assistant \\ Professor of family and community health nursing department, Faculty of nursing, Port
} Said University ${ }^{3,4}$

\begin{abstract}
Background: Hypertension is a chronic disease affecting millions and causing millions of complications every year worldwide. People living with hypertension need to make several lifestyle adjustments, not only for treating hypertension but also for the prevention of other related chronic diseases. Aim: Evaluate the effect of evidence-based lifestyle guidelines on self-efficacy among hypertension patients in Port Said City. Subjects and method: A quasi-experimental design was utilized for conducting this study. Setting: The study was carried out at primary health care centers located in Port Said City. subjects: A purposive sample of 341 patients with hypertension recruited from randomly chosen six primary health care centers. Tools: Data was collected using three tools, Tool I: Self-Administered Structured Questionnaire divided into three parts namely: demographic data, patient' medical history, and knowledge assessment sheet, Tool II: Hypertension self-care activities scale and Tool III: Self-efficacy scale. Results: (4.4\%) of the study group had satisfactory knowledge in the pre implementation phase while after implementation changed to $(94.4 \%)$ of them had satisfactory knowledge. Nearly (4.4\%) of them had an adequate level of selfcare activity while after implementation become (85.9\%). About (2.6\%) only had an adequate level of self-efficacy while after implementation become (97.9\%). Conclusion: most of studied hypertensive patients had unsatisfactory knowledge, non-adherence to selfcare activities and low self-efficacy toward their disease before implementation of evidence-based lifestyle guidelines, while the majority had satisfactory knowledge, adherence to self-care activities and high self-efficacy after implementation of guidelines with highly statistically significant difference. Recommendation: Apply evidence-based lifestyle guidelines more and more to cover all hypertensive patients to help them understanding the nature of their chronic disease and trying to cope without complications.
\end{abstract}

Key Words: Evidence based lifestyle guidelines, hypertension, self-care activity and selfefficacy 


\section{INTRODUCTION}

Hypertension is defined as a medical condition in which the blood pressure in the arteries is elevated exceeding 140 over $90 \mathrm{mmHg}$. This elevation makes the heart work harder than usual to circulate blood through the blood vessels. Many patients suffer from this disease are not aware about this condition early because it is usually occurred without any symptoms. Hypertension takes a long time before diagnosed thereby causing major health problems as damage to organs as the brain and kidneys and so on are the long-term effect of hypertension disease. (Abd El-Hay and El Mezayen, 2015).

Hypertension is a major worldwide public health problem because of its high prevalence with vascular disease, premature death, stroke, renal diseases and retinopathy. (Adebayo1, Rotkangmwa and Shalkur, 2015). International Society of Hypertension and National Blood Pressure Association have declared that more than 50 percentage of people with high blood pressure are not aware of their condition. Also, the success rate for controlling high blood pressure in the USA in just $27 \%$ and this rate in England, France and Germany is even lower (Lauffenburger, Shrank, Bitton, Franklin, Glynn, Krumme and Pezalla et al., 2017).

An Egyptian national survey conducted in 2012 showed a higher prevalence of various cardiovascular risk factors than did the global and regional figures, especially factors like increased body weight, physical inactivity, and low fruit and vegetable consumption. The prevalence of hypertension and tobacco use was also high, $39.7 \%$ and 24.4\% respectively. (Schiffrin, Campbell, Feldman, Kaczorowski, Lewanczuk, Padwal and Tobe et al., 2016). Although hypertension is a preventable and treatable condition but without treatment it leads to serious and life-threatening complications such as heart, kidney and brain disorders which in most cases result in patient's disability (Lauffenburger, Landon and Fischer, 2017).

Continuous monitoring and evaluation of blood pressure could be an important step in successful control of hypertension. The goal of hypertension treatment is to prevent death and complications by achieving and maintaining the blood pressure at $140190 \mathrm{~mm} \mathrm{hg}$ or lower. Lifestyle modification is the first line of intervention for all patients with hypertension, but pharmacological treatment remains the cornerstone for disease management, reduction of blood pressure and prevention of complications such as cardiovascular and renal morbidity and mortality (Behzad, Bastani and Haghani, 2016: Hjornholm, Aamodt, Larstorp, Fadl Elmula and Hoieggen, 2018). 
The latest recommendations for prevention, detection, evaluation, and treatment of hypertension have considerably emphasized the individual's health promotion through the healthy modification of their lifestyle. The control of hypertension through health promotion and life style modification presents a significant challenge for a large segment of the population that is well suited to nursing care (Somayeh, Mohsen and Maryam, 2016). Lifestyle modification is the first step in the management and treatment of hypertension. Lifestyle is usually based on long-standing behavioral patterns, maintained by the social environment. A lifestyle is believed to be the cornerstone of prevention and should be promoted by all the healthcare providers with collaboration of the family (Kim and Kong, 2015). Additionally, lifestyle factors such as increased body weight, excess body fat, high consumption of dietary sodium, excessive consumption of alcohol, smoking and physical inactivity have been implicated in hypertension prevalence (Sarki, Nduka, Stranges, Kandala and Uthman,2015).

Evidence-based nursing practice has been the gold standard for nursing care delivery. Evidence based practice (EBP) incorporates current best evidence, individual clinical expertise and patient preferences in decision-making. Evidence-based clinical guidelines exist that are useful for health screening, health promotion, and the management and treatment of chronic conditions. (Varaei, Salsali, Cheraghi, Tehrani, and Heshmat, 2013). Use of an evidence-based practice (EBP) model can be an important and aid to ensuring consistent patient care among providers, aid in the delivery of quality health care, and cost effectively improve patient outcomes (Harris, Lloyd, Krastev, Fanaian, Gawaine and Zwar, et al., 2014).

The application of evidence-based health promotion in dealing with hypertension is not only a definitive role for nurses practicing, but is also a major contribution to the science of nursing. It should be applicable in any settings including clinical and community settings. In the light of Evidence-based nursing practice, the nursing process is a universal nursing framework and also a unique way of thinking and acting for clients' care based on references (Breckenridge, Aronson, Blaschke, Hartman, Peck and Vrijens, 2017).

Guidelines of different organizations and countries consistently state that lifestyle modifications include weight reduction, adoption of fruits and vegetables in the daily diet, dietary sodium reduction, and physical activity, moderation of alcohol consumption, smoking cessation, and stress management. Current treatment guidelines for hypertension include antihypertensive medications and health-promoting lifestyle modifications(Chin, Twinobuhungiro, Sandhu, Hootsmans, Kayima, and Kalyesubula , 2017). 
Self-efficacy is widely used as psychological concept that has been recognized as an essential prerequisite of effective care of chronic disease. Measuring the self-efficacy in patients with hypertension is an important step towards improving hypertension control in individuals or population level. The information gained from measurement of self-efficacy can help physicians or public health professionals to identify low self-efficacy and implement suitable interventions. (Hu, Li and Arao, 2013).

Community health nurses can play an important role in facilitating patient's selfefficacy to the prescribed treatment regimen. As they responsible to help patients gain knowledge, skills to live with and control hypertension (Mersal and Mersal, 2015).

\section{Significance of the study:}

Hypertension is a chief public health care in both developing and developed countries. It affects approximately I billion individuals worldwide. Hypertension is an urgent health problem in Egypt with prevalence rate of $26.3 \%$ among the adult population, its incidence increases with aging, around $50 \%$ of Egyptians over the age of 60 years have hypertension, besides, it was concluded that there are declines in the levels of awareness of hypertension and even lower levels of control (Alaa, Abdelazim, Emeash ,Hassan and Mustafa, 2014). Lifestyle behavior modifications are the first line of intervention for all patients with hypertension. It should be actively performed not only before but also after starting of antihypertensive medications to improve patients controlling outcomes. (Mersal and Mersal, 2015). Evidence-based nursing practice (EBN) has been the gold standard for nursing care delivery. It defined as the integration of the best possible research. The application of evidence-based health promotion in dealing with hypertension patient is not only a definitive role for nurses practicing, but is also a major contribution to the science of nursing. Therefore, the aim of this study is to evaluate the effect of evidence-based lifestyle guidelines on self-efficacy among hypertensive patients in Port Said city.

\section{AIM OF THIS STUDY:}

This study aimed to evaluate the effect of evidence-based lifestyle guidelines on self-efficacy among hypertension patients in Port Said City.

\section{Objectives of the study:}

1- Assess patient knowledge about hypertension. 
2- Design a plan of evidence-based lifestyle guidelines on self-efficacy of patients with hypertension.

3- Implement a plan of evidence-based lifestyle guidelines on self-efficacy of patients with hypertension.

4- Evaluate the effect of evidence-based lifestyle guidelines on self-efficacy of patients with hypertension.

\section{Hypothesis:}

Hypertensive patients, who would be exposed to the evidence-based lifestyle guidelines, would show improvement on their knowledge, self-care activities and selfefficacy after implementation of guidelines.

\section{SUBJECTS AND METHOD}

\section{Study Design:}

A Quasi-experimental (pre-post-test) design was utilized in the current study.

\section{Study Setting:}

This study was confirmed at six primary health care centers which chosen randomly from seven districts located at Port Said city, namely: ( Bahr El-Bakar from Elganoub district, Elgawharah from Elzohour district, Elkwait from Elmanakh district, El-Arab Medical center from Elarab district, Elkaboty from Eldawahy district \& Elgarabaa from west of Port Said district). Even though El shark district not included in the study because it has not primary health care centers. These centers provide health services for hypertensive patients through chronic disease clinics such as history taking, vital signs measurement, lab investigations and follow up for hypertensive patients and given health education about their condition.

\section{Subjects:}

Subjects of this study consisted of patients diagnosed with hypertension (BP $\geq$ 140/90) who were attending to chronic disease clinics in the previous selected primary health care centers in Port Said City. 


\section{Sampling technique:}

A Cluster sample technique applied to recruit study subjects form six districts located in Port Said City. A simple random selection used to select one center from each above previous listed districts. A purposive sampling technique used to recruit the studied sample. A purposive sample used to select of hypertensive patients who were attending chronic disease clinic located at primary health care center in Port Said city, Egypt.

\section{Sample size:}

The sample size was determined by using the following equation (Charan and Biswas, 2013).

$$
\text { Sample size }=\frac{Z 1-\propto / 2^{2} p(1-p)}{d^{2}}
$$

Where:

$\mathrm{z} 1-\alpha \therefore 2=$ apercentile of standard normal distribution by confidence level $=1.96$

$\mathrm{P}=$ Expected proportion in population based on previous studies (prevalence of hypertension among adult patients $=28 \%$ according to WHO (2017)

D: absolute error or precision $(5 \%)$

Sample size $=\frac{1.96^{2} \times 0.28(1-0.28)}{(0.05)^{2}}=310$

Assuming a $10 \%$ attrition rate:

$10 \%$ of $310=31$

$310+31=341$

The total sample size was 341 patients.

\section{Methods for data collection:}

Three main tools were used to achieve the purpose of the current study as following:

\section{Tool I: Self-Administered Questionnaire:}

This tool was adopted from Mahajan, Kazi, Sharma, Velhal (2012), It was translated from English language to simple Arabic language by English language expertise. it was comprised of three parts: Part I: concerned with demographic characteristics of 
patients, it included 9 items such as age, sex, marital status, level of education... etc. Part II: concerned with patient, s medical history, it included 13 items such as height, weight, body mass index, stage of hypertension ... etc. Part III: concerned with patient's knowledge assessment sheet (pre and post-test): It used to assess the level of patient's knowledge regarding hypertension in the pre implementation phase then used as post-test to evaluate the level of patient's knowledge after the implementation of the guidelines. It consisted of 17 items about hypertension, such as: definition of hypertension, normal range, types of hypertension ,causes, risk factors ,symptoms, complications, management activities , food that increase BP, food that lower BP, food increase weight, effect of exercise, BP measurement ,effect of self-monitoring, effect of smoking ,effect of regular follow up and effect of relaxation technique.

\section{Scoring systems:}

The score one given for each correct answer and zero for incorrect answer. These scores where been converted into a percent score. The total knowledge considered satisfactory if the percent score was $60 \%$ or more and unsatisfactory if less than $60 \%$.

\section{Tool II: Hypertension Self-Care Activities Scale:(pre and post-test)}

This tool adopted from Seymour, Shenk \&Warren-Findlow, (2011) then modified by the researcher after revising of related literature review and opinions of expertise for content of validity. It translated from English language to simple Arabic language by English language expertise and was used to assess the level of hypertension patients' adherence for lifestyle modification in the pre-implementation phase there by evaluation of their level if adherence in the post implementation phase. This scale consisted of 35 items to assess seven aspects of activities for hypertension such as medication use, diet, physical activity, smoking cession, weight management, relaxation technique, self-monitoring and follow up. Every aspect has sub items and rated on a 5-point Likert scale (strongly agree, agree, neither, disagree and strongly disagree.).

\section{Scoring systems:}

The scoring of Self Care Activities for patients with hypertension was been converted into a percent score. Each item is rated on a 5-point Likert scale as: $5=$ strongly agree, $4=$ agree, 3 = neither, 2 = disagree and $1=$ strongly disagree. The total Self Care Activities for patients with hypertension considered adequate if the percent score was $60 \%$ or more and inadequate if less than $60 \%$. 


\section{Tool III: Self-Efficacy Scale :( pre and post -test)}

The scale was adopted from Warren-Findlow, Seymour, \& Brunner,-Huber, (2012), and Schwarzer \& Jerusalem, Generalized self-efficacy scale, 1995, then modified by the researcher after revising of related literature review and opinions of expertise for content of validity. It translated from English language to simple Arabic language by English language expertise. It used to measure the self-efficacy of the selected hypertensive patients before and after implementation of guidelines. The scale consists of 6 items to assess selfefficacy for patients with hypertension such as diet, medication, measurement, follow up, exercise and emotional distress. Each item rated on a 5-point Likert scale from very confident to not confident at all.

\section{Scoring systems:}

The scoring of Self-efficacy scale for patients with hypertension was been converted into a percent score. Each item rated on a 5 -point Likert scale from $5=$ very confident, $4=$ pretty confident, $3=$ somewhat confident, $2=$ not very confident and $1=$ not confident at all. The total Self-efficacy scale considered adequate if the percent score was $60 \%$ or more and inadequate if less than $60 \%$.

\section{Validity of the study tools:}

The instruments translated into Arabic and back translated into English, verifying whether the translation covers all aspects of the original English version of the questionnaire or not. To ensure the face validity of the final translated Arabic version of the questionnaires, experts who selected based on their qualifications and experience in nursing research and education evaluated the tools.

\section{Reliability of the study tools:}

The Cronbach $\alpha$ (coefficient was calculated to assess the reliability of the developed tool through their internal consistency). The Cronbach $\alpha$ for patient knowledge assessment tool was .861 and for hypertension self-care activity scale was .91 and for self-efficacy scale was 0.87 which exceeded the minimally acceptable standard of validity.

\section{Pilot study:}

A pilot study conducted on $10 \%$ (34 patients) of the sample who excluded from the studied sample to test the clarity and applicability of the tools of the study and estimate the 
time required filling in them. It carried out over a period of one month before embarking on the fieldwork of the study (from the beginning to the end of May 2019). The results obtained from the pilot study used to discover any difficulties that might be encountered by the participants in reading or understanding.

\section{Fieldwork:}

This study conducted through four successive phases: assessment, planning, implementation and evaluation. Data collection and implementation of guidelines lasted for about ten months from the beginning of July 2019 to the end of April 2020. The researcher visited the pre-mentioned settings 5 days per week from 8.30 am. to $1 \mathrm{pm}$. Assessment phase consumed two months, planning phase lasted for one month, implementation phase and evaluation phase consumed seven months.

Phase I. (Assessment phase):

After preparing the tool and agreement approved to conduct this study, the researcher was beginning to collect data assembly and met participants who match the conditions. The study sample was recruited and collecting the data baseline. Pre-tested questionnaire administered to the study sample to assess their existing level of knowledge regarding hypertension, their level of self-care activities and their self-efficacy. The selected primary health care centers were visited four days/week from the beginning to the end of the work. The researcher introduced herself to the patients and took the oral consent of them to be recruited in the study after explaining the aim of the study. During the meeting, the researcher reads each item/question on a data collection sheet and explained its meaning to the patients. Then asked the patients and filled by the researcher. It took about (35-40) minutes.

\section{Phase II (Planning phase):}

The lifestyle guidelines content was prepared based on the identified needs and demands of patients gathered in phase (I), and in the light of the most recent pertinent literature. It included the following items: identifying of hypertension, normal value of blood pressure, classifications, its types, causes, risk factors, signs and symptoms, complications. It also covered the importance of self-efficacy and evidence based lifestyle practice which emphasized on eating sensibly, reducing salt, fat, caloric and sugar intake, regular follow-up with the physician, exercise regularly and reducing weight, stop smoking, compliance with prescribed medication and do daily aerobic exercise, the importance and the method of measuring blood pressure and practicing deep breathing exercises. Teaching 
methods selected to suit teaching of small groups in the form of lectures, group discussion, brainstorming, demonstration, and re-demonstration to facilitate comprehension and integration of theory and practice. In addition, teaching media were prepared as power point presentations, CD films, colored posters, and booklet that covered theoretical and practical information.

\section{Phase III (Implementation phase):}

The guidelines for this study carried out in the teaching room affiliated to the prementioned settings. The acceptance of participation was taken after explanation the purpose of the study. Moreover, the Patients grouped; each group included 2-3 patients. The guidelines consisted of 4 sessions; three of the sessions were theoretical about hypertension, lifestyle, self-efficacy and one session was practical. Each session lasted for around 30-35 minutes. It applied through different teaching methods, which included interactive lectures, discussion, instruction media as power point presentations and printed handout (booklet).

The first session covered items of overview about hypertension, definition, and normal range for blood pressure, types, risk factors, causes, symptoms, complications and treatment. This session took about 45 minutes.

The second session covered items of lifestyle modifications including medications adherence, diet, and physical activity and smoking cession. This session took about 40 minutes.

The third session covered self-monitoring, follow up, self-efficacy and its positive effect. This session took about 35 minutes.

The fourth session was practical for training patients how to measure blood pressure and training about deep breathing exercises. This session took about 40 minutes.

- Instructional booklet was given to each patient to attract his/her attention, motivate his/her, and help for reviewing at home and support teaching at home. The instructional booklet consists of the guideline contents; it written in a simple Arabic language and supplemented by photos and illustrations to help the patient understanding of the content involved: definition, risk factors, incidence, signs and symptoms, preventive measures of hypertension, Pharmacological and non-pharmacological treatment and components of 
healthy life style (dietary control, physical exercise, stress management and selfmonitoring)

\section{Phase IV (Evaluation phase):}

The evaluation phase emphasized on estimating the effect of life style guidelines on patients' knowledge, self-care activities and self-efficacy of patients. The posttest conducted immediately for patients after implementation of the lifestyle guidelines; each patient in the study interviewed to evaluate knowledge using the same tools in pretest. The results compared to the pre-test results to evaluate the effect of evidence-based lifestyle guidelines on self-efficacy among hypertensive patients.

\section{Administrative design: -}

Before conduction of study, an official letter explaining the aim of the study was issued from the Dean of the faculty of Nursing, Port Said University to directors of primary health care centers to obtain their permission to conduct the study. Also an approval was taken from the participants themselves, after explanation to each of them the purpose of the study

\section{Ethical Consideration:}

An official approval was obtained from research committee at Faculty of Nursing, Port Said University. And an approval from primary health care centers directors to conduct the study was taken after explanation the aim and process of the study. An oral consent taken from each participant to participate in the study after explanation of the study aim and informed him or her that his/her participation was voluntary and they have the right to withdraw from the study at any time they wish to do. In addition, they were assured about confidentiality and anonymity of information gathered and that was used only for the purpose of the study.

\section{Statistical Design:}

Data fed to the computer and analyzed using IBM SPSS (Statistical Package Social Sciences) software program version 23.0. (Armonk, NY: IBM Corp) Qualitative data described using number and percent. Quantitative data were described using range (minimum and maximum), mean, standard deviation and median. A paired t-test was used to analyze the total scores of the participants responses on the pre-test and the post-test with $\mathrm{P}<0.05$ considered significant. Chi square test, Fisher Exact and McNemar test were used 
to test the correlation between respondents' knowledge and socio-demographic variables. The significance level was reported and pre-settled at $\mathrm{p}<0.05$.

\section{RESULTS:}

It can be seen in table (1), that $64.2 \%$ of the studied sample aged 49 to more than 50 years. About $66.6 \%$ were male. About $81.5 \%$ of the sample were married, $80.6 \%$ of them living in urban area and $79.5 \%$ of them had family members ranging from three to six members. Also $24.9 \%$ of the studied sample were illiterate and about $28.4 \%$ can read and write. About $53.4 \%$ of the studied sample worked as craftsmanship, 51.6\% had not enough monthly income and $63.9 \%$ of them had no health insurance.

Table (2): illustrates that $59.2 \%$ of the studied sample were overweight with mean was $28.55 \pm 3.05$. About $63.3 \%$ had hypertension stage I. In addition, $60.7 \%$ of the studied sample was not smoking and $54.3 \%$ had positive family history of hypertension.

Table (3): clarifies that only $4.4 \%$ had satisfactory about hypertension disease before implementation of the evidence-based guide line lifestyle while it became $94.4 \%$ after implementation of guidelines with high statistically significant difference between total mean scores pre and post at implementation stage at $(\mathrm{p}<0.001)$.

Table (4): shows that there were statistical significance differences between pre and post implementation phase for all item of self-care activity scale with the lowest level of self-care activity was found in the same percentage $7.9 \%$ regarding weight management, relaxation technique and follow up, while the highest level $41.3 \%$ of self-care activities regarding medication use was detected in the pre implementation phase. However, after implementation phase, the lowest level of self-care activity was regarding smoking with $56 \%$ while the highest level of self-care activities regarding self-care activity of selfmonitoring was $97.4 \%$.

The comparison between total mean scores \& percentage score pre and post hypertension self-care activities scale (H-scale) dimensions among the studied sample showed in table (5). It was observed that $4.4 \%$ of the studied sample had an adequate level of total self-care activity before implementation of the evidence based lifestyle guidelines while after implementation became $85.9 \%$, with high statistically significant difference between total mean scores pre and post at implementation stage at $(\mathrm{p}<0.001)$. 
In relation to self-efficacy assessment scale, demonstrated in table (6), that $2.6 \%$ had an adequate level of self-efficacy before implementation of evidence based lifestyle guidelines compared to $97.9 \%$ after implementation of guidelines.

Table (7): indicates that there was a highly statistically significant relation between self-efficacy with knowledge and Self-monitoring at $(\mathrm{p}<0.001)$, while there was a statistical significant relation with physical activity, smoking, relaxation technique and follow up at $(\mathrm{p}=0.002, \mathrm{p}=0.019,0 . \mathrm{p}=0.017$ and $\mathrm{p}=0.009)$ respectively.

Table (1): Distribution of the studied sample according to socio-demographic characteristics: $(\mathrm{n}=341)$

\begin{tabular}{|c|c|c|}
\hline Items & No. & $\%$ \\
\hline \multicolumn{3}{|l|}{ Age } \\
\hline $30-39$ & 12 & 3.5 \\
\hline $40-49$ & 110 & 32.3 \\
\hline $50+$ & 219 & 64.2 \\
\hline Min. - Max. & \multicolumn{2}{|c|}{$35.0-67.0$} \\
\hline Mean \pm SD & \multicolumn{2}{|c|}{$51.56 \pm 6.46$} \\
\hline \multicolumn{3}{|l|}{ Sex } \\
\hline Male & 227 & 66.6 \\
\hline Female & 114 & 33.4 \\
\hline \multicolumn{3}{|l|}{ Marital Status } \\
\hline Single & 3 & .9 \\
\hline Married & 278 & 81.5 \\
\hline Widowed & 42 & 12.3 \\
\hline Divorced & 18 & 5.3 \\
\hline \multicolumn{3}{|l|}{ Site of residence } \\
\hline Rural & 66 & 19.4 \\
\hline Urban & 275 & 80.6 \\
\hline \multicolumn{3}{|c|}{ Number of family members } \\
\hline$<3$ & 12 & 3.5 \\
\hline $3-6$ & 271 & 79.5 \\
\hline$>6$ & 58 & 17.0 \\
\hline Min. - Max. & \multicolumn{2}{|c|}{$1.0-9.0$} \\
\hline Mean \pm SD & \multicolumn{2}{|c|}{$5.33 \pm 1.39$} \\
\hline \multicolumn{3}{|l|}{ Level of education } \\
\hline Illiterate & 85 & 24.9 \\
\hline Primary/preparatory & 97 & 28.4 \\
\hline Secondary & 97 & 28.5 \\
\hline University & 62 & 18.2 \\
\hline \multicolumn{3}{|l|}{ occupation } \\
\hline Craftsmanship & 182 & 53.4 \\
\hline Employee & 111 & 32.6 \\
\hline Not Work & 0 & 0 \\
\hline housewife & 48 & 14.1 \\
\hline \multicolumn{3}{|l|}{ Monthly income } \\
\hline Enough & 165 & 48.4 \\
\hline Not enough & 176 & 51.6 \\
\hline \multicolumn{3}{|l|}{ Health insurance } \\
\hline yes & 123 & 36.1 \\
\hline No & 218 & 63.9 \\
\hline
\end{tabular}


Table (2): Distribution of the studied sample according to their medical history $(\mathrm{n}=341)$

\begin{tabular}{|c|c|c|}
\hline Items & No. & $\%$ \\
\hline \multicolumn{3}{|l|}{ Height } \\
\hline Min. - Max. & \multicolumn{2}{|c|}{$160.0-187.0$} \\
\hline Mean \pm SD. & \multicolumn{2}{|c|}{$171.62 \pm 6.47$} \\
\hline \multicolumn{3}{|l|}{ Weight } \\
\hline Min. - Max. & \multicolumn{2}{|c|}{$60.0-110.0$} \\
\hline Mean \pm SD. & \multicolumn{2}{|c|}{$84.08 \pm 9.88$} \\
\hline \multicolumn{3}{|c|}{ Body mass index (BMI) } \\
\hline Normal & 39 & 11.4 \\
\hline Overweight & 202 & 59.2 \\
\hline Obese Class I & 94 & 27.6 \\
\hline Obese Class II & 6 & 1.8 \\
\hline Min. - Max. & \multicolumn{2}{|c|}{$22.58-38.06$} \\
\hline Mean \pm SD. & \multicolumn{2}{|c|}{$28.55 \pm 3.05$} \\
\hline \multicolumn{3}{|l|}{ Blood pressure } \\
\hline Prehypertension & 18 & 5.3 \\
\hline Stage I & 216 & 63.3 \\
\hline Stage II & 107 & 31.4 \\
\hline \multicolumn{3}{|l|}{ Smoking } \\
\hline Yes & 134 & 39.3 \\
\hline No & 207 & 60.7 \\
\hline \multicolumn{3}{|l|}{ If smoking $(n=134)$} \\
\hline \multicolumn{3}{|c|}{ Cons umption of tobacco per day } \\
\hline$<10$ & 3 & 0.9 \\
\hline $10-20$ & 92 & 27.0 \\
\hline$>20$ & 39 & 11.4 \\
\hline Min. - Max. & \multicolumn{2}{|c|}{$8.0-35.0$} \\
\hline Mean \pm SD. & \multicolumn{2}{|c|}{$20.47 \pm 6.32$} \\
\hline \multicolumn{3}{|c|}{ Number of years smoked } \\
\hline$<5$ & 3 & 0.9 \\
\hline $5-<10$ & 3 & 0.9 \\
\hline $10-<15$ & 28 & 8.2 \\
\hline $15-20$ & 100 & 29.3 \\
\hline Min. - Max. & \multicolumn{2}{|c|}{$3.0-30.0$} \\
\hline Mean \pm SD & \multicolumn{2}{|c|}{$18.46 \pm 6.45$} \\
\hline \multicolumn{3}{|c|}{ Duration of hypertension } \\
\hline$<5$ & 153 & 44.9 \\
\hline $5-<10$ & 110 & 32.3 \\
\hline $10-<15$ & 66 & 19.4 \\
\hline $15-20$ & 12 & 3.5 \\
\hline Min. - Max. & \multicolumn{2}{|c|}{$1.0-20.0$} \\
\hline Mean \pm SD. & \multicolumn{2}{|c|}{$6.25 \pm 3.98$} \\
\hline \multicolumn{3}{|l|}{ Family his tory of HIN } \\
\hline yes & 185 & 54.3 \\
\hline No & 156 & 45.7 \\
\hline Associated chronic di & & \\
\hline yes & 98 & 28.7 \\
\hline No & 243 & 71.3 \\
\hline Use of concurrent dru & & \\
\hline yes & 95 & 27.9 \\
\hline No & 246 & 72.1 \\
\hline
\end{tabular}


Table (3): Comparison between studied sample on pre and post total mean score \& \% score of knowledge $(\mathrm{n}=341)$

\begin{tabular}{|c|c|c|c|c|c|c|}
\hline & \multicolumn{2}{|c|}{ Pre } & \multicolumn{2}{|c|}{ Post } & \multirow{2}{*}{$\begin{array}{c}\text { Test of } \\
\text { sig. }\end{array}$} & \multirow[t]{2}{*}{$\mathbf{p}$} \\
\hline & No. & $\%$ & No. & $\%$ & & \\
\hline \multicolumn{7}{|l|}{ Knowledge } \\
\hline$<60 \%$ Unsatisfactory & 326 & 95.6 & 19 & 5.6 & \multirow{2}{*}{$\begin{array}{c}\mathrm{McN}= \\
305.003^{*}\end{array}$} & \multirow[t]{2}{*}{$<0.001^{*}$} \\
\hline$\geq 60$ Satisfactory & 15 & 4.4 & 322 & 94.4 & & \\
\hline \multicolumn{7}{|l|}{ Total score } \\
\hline Min. - Max. & \multicolumn{2}{|c|}{$0.0-15.0$} & \multicolumn{2}{|c|}{$7.0-17.0$} & \multirow{5}{*}{$\begin{array}{c}\mathrm{t}= \\
53.159^{*}\end{array}$} & \multirow[t]{5}{*}{$<0.001^{*}$} \\
\hline Mean \pm SD. & \multicolumn{2}{|c|}{$3.94 \pm 3.45$} & \multicolumn{2}{|c|}{$14.68 \pm 2.11$} & & \\
\hline \multicolumn{5}{|l|}{ \% score } & & \\
\hline Min. - Max. & \multicolumn{2}{|c|}{$0.0-88.24$} & \multicolumn{2}{|c|}{$41.18-100.0$} & & \\
\hline Mean \pm SD. & \multicolumn{2}{|c|}{$23.15 \pm 20.28$} & \multicolumn{2}{|c|}{$86.36 \pm 12.39$} & & \\
\hline
\end{tabular}

$\mathrm{McN}: \mathrm{McNemar}$ test t: Paired t-test

$\mathrm{p}$ : $\mathrm{p}$ value for comparing between pre and post

*: Statistically significant at $\mathrm{p} \leq 0.05$

Table (4): Comparison between studied sample on pre and post assessment of hypertension self-care activities scale $(\mathrm{H}$-scale) dimensions $(\mathrm{n}=341)$

\begin{tabular}{|c|c|c|c|c|c|c|}
\hline \multirow{2}{*}{$\begin{array}{c}\text { Items of Self Care } \\
\text { Activities Scale }\end{array}$} & \multicolumn{2}{|c|}{ Pre } & \multicolumn{2}{|c|}{ Post } & \multirow{2}{*}{$\mathbf{M c N}$} & \multirow{2}{*}{$\mathbf{p}$} \\
\hline & No. & $\%$ & No. & $\%$ & & \\
\hline \multicolumn{7}{|l|}{ Medication use } \\
\hline $\begin{array}{l}<60 \% \text { Inadequate } \\
\geq 60 \text { Adequate }\end{array}$ & $\begin{array}{l}200 \\
141\end{array}$ & $\begin{array}{l}58.7 \\
41.3\end{array}$ & $\begin{array}{c}15 \\
326\end{array}$ & $\begin{array}{c}4.4 \\
95.6\end{array}$ & $183.005^{*}$ & $<0.001^{*}$ \\
\hline \multicolumn{7}{|l|}{ Low-salt Diet } \\
\hline $\begin{array}{l}<60 \% \text { Inadequate } \\
\geq 60 \text { Adequate }\end{array}$ & $\begin{array}{c}296 \\
45\end{array}$ & $\begin{array}{l}86.8 \\
13.2\end{array}$ & $\begin{array}{l}146 \\
195\end{array}$ & $\begin{array}{l}42.8 \\
57.2\end{array}$ & $102.782^{*}$ & $<0.001^{*}$ \\
\hline \multicolumn{7}{|l|}{ Physical Activity } \\
\hline $\begin{array}{l}<60 \% \text { Inadequate } \\
\geq 60 \text { Adequate }\end{array}$ & $\begin{array}{c}311 \\
30\end{array}$ & $\begin{array}{c}91.2 \\
8.8\end{array}$ & $\begin{array}{c}34 \\
307\end{array}$ & $\begin{array}{l}10.0 \\
90.0\end{array}$ & $275.004^{*}$ & $<0.001^{*}$ \\
\hline \multicolumn{7}{|l|}{ Smoking } \\
\hline $\begin{array}{l}<60 \% \text { Inadequate } \\
\geq 60 \text { Adequate }\end{array}$ & $\begin{array}{c}278 \\
63\end{array}$ & $\begin{array}{l}81.5 \\
18.5\end{array}$ & $\begin{array}{l}150 \\
191\end{array}$ & $\begin{array}{l}44.0 \\
56.0\end{array}$ & $98.348^{*}$ & $<0.001^{*}$ \\
\hline \multicolumn{7}{|l|}{ Weight Management } \\
\hline $\begin{array}{l}<60 \% \text { Inadequate } \\
\geq 60 \text { Adequate }\end{array}$ & $\begin{array}{c}314 \\
27\end{array}$ & $\begin{array}{c}92.1 \\
7.9\end{array}$ & $\begin{array}{c}27 \\
314\end{array}$ & $\begin{array}{r}7.9 \\
92.1\end{array}$ & $285.00^{*}$ & $<0.001^{*}$ \\
\hline \multicolumn{7}{|l|}{ Relaxation technique } \\
\hline $\begin{array}{l}<60 \% \text { Inadequate } \\
\geq 60 \text { Adequate }\end{array}$ & $\begin{array}{c}314 \\
27\end{array}$ & $\begin{array}{c}92.1 \\
7.9\end{array}$ & $\begin{array}{c}30 \\
311\end{array}$ & $\begin{array}{c}8.8 \\
91.2\end{array}$ & $282.00^{*}$ & $<0.001^{*}$ \\
\hline \multicolumn{7}{|l|}{ Self-monitoring } \\
\hline $\begin{array}{l}<60 \% \text { Inadequate } \\
\geq 60 \text { Adequate }\end{array}$ & $\begin{array}{c}292 \\
49\end{array}$ & $\begin{array}{l}85.6 \\
14.4\end{array}$ & $\begin{array}{c}9 \\
332\end{array}$ & $\begin{array}{c}2.6 \\
97.4\end{array}$ & $281.00^{*}$ & $<0.001^{*}$ \\
\hline \multicolumn{7}{|l|}{ Follow up } \\
\hline $\begin{array}{l}<60 \% \text { Inadequate } \\
\geq 60 \text { Adequate }\end{array}$ & $\begin{array}{c}314 \\
27\end{array}$ & $\begin{array}{c}92.1 \\
7.9\end{array}$ & $\begin{array}{c}24 \\
317\end{array}$ & $\begin{array}{c}7.0 \\
93.0\end{array}$ & $288.00^{*}$ & $<0.001^{*}$ \\
\hline
\end{tabular}

\section{McN McNemar test}

$\mathrm{p}$ : $\mathrm{p}$ value for comparing between pre and post * Statistically significant at $\mathrm{p} \leq 0.05$ 
Table (5): Comparison between studied sample on pre and post overall scores of hypertension Self Care Activities Scale $(\mathrm{H}-\mathrm{Scale})(\mathrm{n}=341)$

\begin{tabular}{|c|c|c|c|c|c|c|}
\hline \multirow[t]{2}{*}{ Items } & \multicolumn{2}{|c|}{ Pre } & \multicolumn{2}{|c|}{ Post } & \multirow{2}{*}{$\begin{array}{l}\text { Test of } \\
\text { sig. }\end{array}$} & \multirow[t]{2}{*}{$\mathbf{p}$} \\
\hline & No. & $\%$ & No. & $\%$ & & \\
\hline \multicolumn{7}{|l|}{ Overall } \\
\hline$<60 \%$ Inadequate & 326 & 95.6 & 48 & 14.1 & \multirow{2}{*}{$\begin{array}{c}\mathrm{McN}= \\
276.004^{*}\end{array}$} & \multirow{2}{*}{$\underset{*}{<0.001}$} \\
\hline$\geq 60$ Adequate & 15 & 4.4 & 293 & 85.9 & & \\
\hline \multicolumn{7}{|l|}{ Total score } \\
\hline Min. - Max. & 58.0 & -131.0 & 75.0 & -153.0 & \multirow{5}{*}{$\begin{array}{c}\mathrm{t}= \\
47.058^{*}\end{array}$} & \multirow{5}{*}{$\underset{*}{<0.001}$} \\
\hline Mean \pm SD. & \multicolumn{2}{|c|}{$\begin{array}{c}86.56 \pm \\
12.73\end{array}$} & \multicolumn{2}{|c|}{$\begin{array}{c}132.04 \pm \\
14.80\end{array}$} & & \\
\hline \multicolumn{5}{|l|}{ \% score } & & \\
\hline Min. - Max. & \multicolumn{2}{|c|}{$\begin{array}{c}17.65- \\
71.32\end{array}$} & \multicolumn{2}{|c|}{$\begin{array}{c}30.15- \\
87.50\end{array}$} & & \\
\hline Mean \pm SD. & \multicolumn{2}{|c|}{$\begin{array}{c}38.65 \pm \\
9.36\end{array}$} & \multicolumn{2}{|c|}{$\begin{array}{c}72.09 \pm \\
10.89\end{array}$} & & \\
\hline
\end{tabular}

McN : McNemar test

t: Paired t-test

$\mathrm{p}$ : $\mathrm{p}$ value for comparing between pre and post

*: Statistically significant at $\mathrm{p}<0.001$

Table (6): Comparison between pre and post overall scores of self-efficacy $(n=341)$

\begin{tabular}{|c|c|c|c|c|c|c|}
\hline \multirow[b]{2}{*}{ Self-efficacy } & \multicolumn{2}{|c|}{ Pre } & \multicolumn{2}{|c|}{ Post } & \multirow{2}{*}{$\begin{array}{l}\text { Test of } \\
\text { sig. }\end{array}$} & \multirow[b]{2}{*}{$\mathbf{p}$} \\
\hline & No. & $\%$ & No. & $\%$ & & \\
\hline \multicolumn{7}{|l|}{ Overall } \\
\hline $\begin{array}{l}<60 \% \text { Inadequate } \\
\geq 60 \text { Adequate }\end{array}$ & $\begin{array}{c}332 \\
9\end{array}$ & $\begin{array}{r}97.4 \\
2.6\end{array}$ & $\begin{array}{c}7 \\
334\end{array}$ & $\begin{array}{r}2.1 \\
97.9\end{array}$ & $\begin{array}{c}\mathrm{McN}= \\
323.003^{*}\end{array}$ & $<0.001^{*}$ \\
\hline \multicolumn{7}{|l|}{ Total score } \\
\hline $\begin{array}{l}\text { Min. - Max. } \\
\text { Mean } \pm \text { SD. }\end{array}$ & $9.96 \pm 3.15$ & $\begin{array}{l}2.0 \\
3.15\end{array}$ & $\begin{array}{r}20.0 \\
26.7\end{array}$ & $\begin{array}{l}30.0 \\
2.08\end{array}$ & \multirow{3}{*}{$\begin{array}{c}\mathrm{t}= \\
94.887^{*}\end{array}$} & \multirow{3}{*}{$<0.001^{*}$} \\
\hline$\%$ score & & & & & & \\
\hline $\begin{array}{l}\text { Min. - Max. } \\
\text { Mean } \pm \text { SD. }\end{array}$ & $\begin{array}{r}0.0 \\
16.52\end{array}$ & $\begin{array}{l}6.7 \\
13.14\end{array}$ & $\begin{array}{l}58.3 \\
86.5\end{array}$ & $\begin{array}{l}00.0 \\
8.68\end{array}$ & & \\
\hline
\end{tabular}

McN : McNemar test

\section{t: Student t-test}

$\mathrm{p}$ : $\mathrm{p}$ value for comparing between pre and post

*: Statistically significant at $\mathrm{p} \leq 0.05$ 
Table (7): Relation between Overall Self-efficacy and Patient's knowledge and Hypertension Self-Care Activities Scale $(\mathrm{n}=341)$

\begin{tabular}{|c|c|c|c|c|c|c|}
\hline \multirow{3}{*}{ Items } & \multicolumn{4}{|c|}{ Overall Self-efficacy } & \multirow{3}{*}{$\chi^{2}$} & \multirow{3}{*}{$\mathbf{F E}_{\mathbf{p}}$} \\
\hline & \multicolumn{2}{|c|}{$\begin{array}{c}\text { Inadequate } \\
(\mathbf{n}=7)\end{array}$} & \multicolumn{2}{|c|}{$\begin{array}{c}\text { Adequate } \\
(\mathrm{n}=334)\end{array}$} & & \\
\hline & No. & $\%$ & No. & $\%$ & & \\
\hline \multicolumn{7}{|l|}{ Knowledge } \\
\hline $\begin{array}{l}<60 \text { Inadequate } \\
\geq 60 \text { Adequate }\end{array}$ & $\begin{array}{l}4 \\
3\end{array}$ & $\begin{array}{l}57.1 \\
42.9\end{array}$ & $\begin{array}{c}15 \\
319\end{array}$ & $\begin{array}{c}4.5 \\
95.5\end{array}$ & $36.126^{*}$ & $<0.001^{*}$ \\
\hline \multicolumn{7}{|l|}{ Medication use } \\
\hline $\begin{array}{l}<60 \text { Inadequate } \\
\geq 60 \text { Adequate }\end{array}$ & $\begin{array}{l}0 \\
7\end{array}$ & $\begin{array}{c}0.0 \\
100.0\end{array}$ & $\begin{array}{c}15 \\
319 \\
\end{array}$ & $\begin{array}{r}4.5 \\
95.5 \\
\end{array}$ & 0.329 & 1.000 \\
\hline \multicolumn{7}{|l|}{ Low-salt Diet } \\
\hline $\begin{array}{l}<60 \text { Inadequate } \\
\geq 60 \text { Adequate }\end{array}$ & $\begin{array}{l}4 \\
3 \\
\end{array}$ & $\begin{array}{l}57.1 \\
42.9 \\
\end{array}$ & $\begin{array}{l}142 \\
192 \\
\end{array}$ & $\begin{array}{l}42.5 \\
57.5 \\
\end{array}$ & 0.599 & 0.467 \\
\hline \multicolumn{7}{|c|}{ Physical Activity } \\
\hline $\begin{array}{l}<60 \text { Inadequate } \\
\geq 60 \text { Adequate }\end{array}$ & $\begin{array}{l}4 \\
3\end{array}$ & $\begin{array}{l}57.1 \\
42.9\end{array}$ & $\begin{array}{c}30 \\
304\end{array}$ & $\begin{array}{c}9.0 \\
91.0\end{array}$ & $17.716^{*}$ & $0.002^{*}$ \\
\hline \multicolumn{7}{|l|}{ Smoking } \\
\hline $\begin{array}{l}<60 \text { Inadequate } \\
\geq 60 \text { Adequate }\end{array}$ & $\begin{array}{l}0 \\
7\end{array}$ & $\begin{array}{c}0.0 \\
100.0\end{array}$ & $\begin{array}{l}150 \\
184\end{array}$ & $\begin{array}{l}44.9 \\
55.1\end{array}$ & $5.613^{*}$ & $0.019^{*}$ \\
\hline \multicolumn{7}{|c|}{ Weight Management } \\
\hline $\begin{array}{l}<60 \text { Inadequate } \\
\geq 60 \text { Adequate }\end{array}$ & $\begin{array}{l}0 \\
7\end{array}$ & $\begin{array}{c}0.0 \\
100.0\end{array}$ & $\begin{array}{c}27 \\
307\end{array}$ & $\begin{array}{c}8.1 \\
91.9\end{array}$ & 0.615 & 1.000 \\
\hline \multicolumn{7}{|c|}{ Relaxation technique } \\
\hline $\begin{array}{l}<60 \text { Inadequate } \\
\geq 60 \text { Adequate }\end{array}$ & $\begin{array}{l}3 \\
4\end{array}$ & $\begin{array}{l}42.9 \\
57.1\end{array}$ & $\begin{array}{c}27 \\
307\end{array}$ & $\begin{array}{c}8.1 \\
91.9\end{array}$ & $10.333^{*}$ & $0.017^{*}$ \\
\hline \multicolumn{7}{|l|}{ Self-monitoring } \\
\hline $\begin{array}{l}<60 \text { Inadequate } \\
\geq 60 \text { Adequate }\end{array}$ & $\begin{array}{l}3 \\
4\end{array}$ & $\begin{array}{l}42.9 \\
57.1\end{array}$ & $\begin{array}{c}6 \\
328\end{array}$ & $\begin{array}{c}1.8 \\
98.2\end{array}$ & $44.985^{*}$ & $<0.001^{*}$ \\
\hline \multicolumn{7}{|l|}{ Follow up } \\
\hline $\begin{array}{l}<60 \text { Inadequate } \\
\geq 60 \text { Adequate }\end{array}$ & $\begin{array}{l}3 \\
4\end{array}$ & $\begin{array}{l}42.9 \\
57.1\end{array}$ & $\begin{array}{c}21 \\
313\end{array}$ & $\begin{array}{c}6.3 \\
93.7\end{array}$ & ${ }^{*} 14.014$ & $0.009^{*}$ \\
\hline \multicolumn{7}{|l|}{ Overall H care } \\
\hline $\begin{array}{l}<60 \text { Inadequate } \\
\geq 60 \text { Adequate }\end{array}$ & $\begin{array}{l}0 \\
7\end{array}$ & $\begin{array}{c}0.0 \\
100.0\end{array}$ & $\begin{array}{c}48 \\
286\end{array}$ & $\begin{array}{l}14.4 \\
85.6\end{array}$ & 1.171 & 0.599 \\
\hline
\end{tabular}

$\chi^{2}$ : Chi square test

FE: Fisher Exact

*: Statistically significant at $\mathrm{p} \leq 0.05$ 


\section{DISCUSSION}

Hypertension progressively and permanently damages target organs, lead to lifethreatening complications and death. A lack of knowledge about hypertension negatively influences patients' awareness and behaviors and is a major obstacle in controlling the disease; as well the poor control of hypertension is attributed to poor patients' self-efficacy with the treatment regimen Khosravizade, Hassanzadeh, and Mostafavi, (2015).

Lifestyle behavior modifications is the first line of intervention for all patients with hypertension, in combination with pharmacological treatment which is also important for the disease management to control its progress and prevent short and long term complications Abd elhay and Elmezayen,(2015). The primary aim of this study was to evaluate the effect of evidence-based life style guidelines on self-efficacy among hypertension patients at Port Said City.

In the light of the findings of the current study, it was shown that more than half of participants were overweight. This results were supported by the study of" Long-term outcomes from healthy eating and exercise lifestyle program for overweight people with heart disease and diabetes" which was confirmed with Alharbi, Gallagher, Kirkness, Sibbritt, \& Tofler, 2016 in Australia who added that being overweight comes with a lot of help related risks, including development of hypertension and diabetes mellitus. This result could be attributed to the fact that being overweight leads to little physical activity as well as accumulation of fats on the walls of arteries that made arteries more narrower leading to hypertension.

Concerning duration of hypertension disease, the current study revealed that more than two fifth of studied subject had diagnosed with hypertension since less than five years. These findings were consistent with Sabouhi, Babaee, Naji, and Zadeh, (2011) who conducted a study in Iran about " Knowledge, awareness, attitudes and practice about hypertension in hypertensive patients referring to public health care centers in Khoor and Biabanak" who mentioned that about three fifth had hypertension since less than ten years.

Furthermore, the present study result showed that about more than half of participants had positive family history of hypertension. This result was in agreement with the study carried out in Mongolia by Demaio, Otgontuya, de Courten, Bygbjerg, Enkhtuya, Oyunbileg, et al. ,2013) about "Hypertension and hypertension-related disease in Mongolia; findings of a national knowledge, attitudes and practices study who said that the 
most risk factors for hypertension known to the subjects were family history $(56.1 \%)$, followed by excessive salt intake $(21.8 \%)$ and the least was alcohol intake $(7.4 \%)$. This indicated that hypertension is an inherited disease and is widespread in many Egyptian families.

The present study showed that most of participants had unsatisfactory level of knowledge about hypertension before implementation of evidence-based guidelines and it was improved after implementation of guidelines. This finding is supported by Jarelnape, 2016 in their study on "The effect of health educational program on patients' knowledge about hypertension and its' management In Sudan - White Nile State" who found that the most of the patients did not have an adequate level of knowledge about hypertension pretest, while as; Post-test after intervention ,the majority of patients had good knowledge to adjust their blood pressure lifestyle changes involving dietary and exercise being effective in significant decrease in weight, and effective in improving patient's knowledge. This might be attributed to the educational level of the subjects, where about one quarter of them were illiterate and more than one quarter had primary level of education.

Regarding practices how patients deal with their hypertension disease. It was observed that the most of them had an inadequate level of practice about blood pressure measurement, relaxation exercises and weight management that significantly improved after patients' involvement in the guidelines sessions. These findings were in the same line with Ez Elregal, (2014) in Ain Shams University who reported in their study about "Promoting Health behaviors of Clients with Hypertensive Kidney Disease by Using Health Promotion Model" that there was improvement of practice about blood pressure measurement, breathing exercises and Progressive Muscle Relaxation after program. It might be due to that the patient required enough instructions about practices that help in minimizing occurrence of stress.

Regarding medication use, the current study revealed that the majority of participants accepted the step of taking medication regularly in the same time with the same dose according to physician order to avoid possible complications, with a statistical difference between pre and post implementation of the guidelines. This finding approved by Abdul Rahman, Wang, Yiu Kwong, Morales, Sritara and Sukmawan, (2015) who mentioned in their study about "Perception of hypertension management by patients and doctors in Asia " that hypertensive patients agreed that successful hypertension management was not defined by reaching a target blood pressure, but rather, involved 
taking their medication regularly, attending scheduled check-ups with their doctor, having their blood pressure measured, and experiencing a lack of symptoms.

Pertaining to the results of this study, the majority of participants had inadequate practice related to low salt diet in the self-care activity scale came in the lowest level of adherence in the pre and post implementation phase this may be due to difficulty in change of diet habits and the pleasure of eating fast food. This result was in accordance with Abd ElHay and ElMezayen (2015) who said in their study about" Knowledge and perceptions related to hypertension, lifestyle behavior modifications and challenges that facing hypertensive patients "that although participants hardly disagreed on the negative effects of salt, they perceived more beliefs regarding barriers to tasteless food when prepared with little salt, confirming the feeling of pleasure when consuming salty food.

As regard to physical activity, the current study revealed that there was statistical difference between pre and post application of guidelines where the majority of subjects follow regular physical activity after implementation. This finding was in line with the study confirmed with Subramanian, Soudarssanane, Jayalakshmy, Thiruselvakumar, Navasakthi \& Ajit Sahai, et al., (2011) on " Non-pharmacological Interventions in Hypertension: A Community-based Cross-over Randomized Controlled Trial "who showed that physical exercise is the most effective choice of nursing guideline program interventions and emphasized that exercise is a cornerstone therapy for the prevention, treatment and control of hypertension. This result could be attributed to that subjects conceived the benefits of regular physical activity and its vital effects in body general health and weight management.

In relation to smoking, the current study results revealed that there was a statistical difference between and after implementation of guidelines. These results were supported by the study of "Measure Outcomes of Patients' Instructions about Modifiable Risk Factors for Hypertensive Patients on Their Attitude and Lipid Profile" done by Hammed, Sherif , Mahdy and Arafat ,(2019) who mentioned that there were marked changes of lifestyle behavior (Diet, exercise, medication, smoking, and psychological) from poor practice in pre-intervention to good practice in follow-up phase with highly statistically significant difference among study phases in all items. It could be attributed to the idea that subjects did not realize the dangerous effect of smoking and its negative impact in developing hypertension. 
In relation to weight reduction, there was a highly statistically difference between pre and post application of guidelines. This result matched with Ahmed, Taha, Ali and Abd EL-Razi, (2017) in their study about "Effect of an educational program on knowledge and self-efficacy of patients with essential hypertension toward therapeutic regimen "who found there was difference between pre and post program regarding weight reduction. This result might be due to that the majority of participants had realized the dangerous effect of overweight on blood pressure. Obesity and overweight are important risk factors contributing to the development of hypertension.

The present study results showed that following relaxation technique scores had improved in the post program to high level of adherence. This result came in line with Kofi, (2011) in their study on " Prevention and Management of Hypertension: A study on knowledge and attitudes of women of childbearing age "who mentioned that most of the hypertensive patients believed that avoiding stress could prevent and control hypertension. This indicated that there was an increase in the subjects' awareness about the positive action of relaxation techniques after implementation of guidelines.

According to the results of the present study, there was highly statistical difference between pre and post-test results regarding self-monitoring where the majority of participants perceived the importance of self-monitoring This results came in the same line with Sanders, Loveday, Pearson, Edwardson, Yates , Biddle et al., (2016) on their study of "Devices for Self-Monitoring Sedentary Time or Physical Activity: A Scoping Review who believed that self-monitoring may contribute to maintaining healthy behaviors and improving health outcomes. This could be explained that the guidelines were effective in educating the subjects the right technique for measuring blood pressure.

Concerning follow up adherence, there was highly statistically difference between pre and post implementation of guidelines. This was in accordance with the study done by AlAli and Elzubair, (2016 ) about " Establishing rapport: Physicians' practice and attendees' satisfaction at a primary health care center, Dammam, Saudi Arabia" who believed that frequent visits to doctors can raise patients' understanding of effective hypertension care and improve communications between patients and doctors. Frequent visits to primary health care centers can also improve the rapport between patients and doctors. This could be explained that the majority of participants in the post program phase realized that follow up was an important step towards hypertension control. 
The present study results revealed that evidence based lifestyle guideline implementation was enhanced self-care activities with highly statistically significant difference between pre and post implementation phase. These results are in consistent with the study on " Knowledge and lifestyle practices of hypertensive patients attending a primary health care clinic in Botswana " in Nigeria conducted by Zangu and Djumbe ,(2018) who revealed that participant's knowledge of recommended lifestyle practices for hypertensive individuals varied from average to high as almost all of them gave a correct response for practices related to smoking and stress. These results reflected the lack of awareness of the subjects towards hypertension self-care activities before implementation of guidelines.

Regarding self-efficacy, this present study showed that there was highly statistically difference between pre and post implementation of the guidelines. This finding was in accordance with $\mathrm{Hu}, \mathrm{Li}$ and Arao (2013) in their study on " Validation of a Chinese Version of the Self-Efficacy for Managing Chronic Disease 6-Item Scale in Patients with Hypertension in Primary Care" who found self-efficacy had been recognized as a major predictor of self-care behavior for chronic disease management as adopting healthy diet and regular exercise, reported better health status, and lower psychological distress. This may be because most hypertensive patients already know what actions they should take, such as weight loss, smoking cessation or participating in exercise activities, but knowledge is insufficient to stimulate actions. Patients need to believe in their capability and have confidence to perform the expected behavior.

Finally, the present study results showed that implementation of the evidence based lifestyle guidelines enhanced self-efficacy of participants with high statistical significant difference between pre and post implementation phase of the guidelines. These results are in line with Ahmed, et al., (2017) on their study about "Effect of an Educational Program on Knowledge and Self-Efficacy of Patients with Essential Hypertension toward Therapeutic Regimen". who mentioned that, patients with higher self- efficacy levels are more likely to start or maintain a specific task even in face of existing barriers. Several self -management programs successfully targeted self-efficacy resulting in improved health outcomes. 


\section{CONCLUSION}

\section{Based on the results of the present study:}

It was concluded that, most of the studied hypertensive patients had unsatisfactory knowledge toward their disease before implementation phase of evidence-based lifestyle guidelines, while the majority had satisfactory knowledge after implementation phase with highly statistically significant difference. Also, the present study results concluded that most of the studied sample had inadequate level of adherence to self-care activities before implementation of evidence-based lifestyle guidelines while after implementation the majority had adequate level of adherence to self-care activities with highly statistically significant difference. Furthermore, the current study revealed that the majority of hypertensive patients included in the present study had low level of self-efficacy before implementation of the guidelines while the results had changed after implementation to become, most of patient $\mathrm{s}$ had sufficient level of self-efficacy towards their chronic disease.

\section{RECOMMENDATIONS}

\section{In the light of the present study results, the following recommendations are:}

1. Apply evidence-based lifestyle guidelines more and more to cover all hypertensive patients to help them understanding the nature of their chronic disease and trying to cope without any complications.

2. Provide medical clinics in primary health care centers with simple guidelines booklets, posters and pamphlets containing all necessary information and practice about how to act with hypertension to hypertensive patients to help them to remember the information on need and facilitate adherence to self-care activities.

3. Encourage hypertensive patients to participate in health education and counseling programs about healthy lifestyle and explain its importance and their impacts in decreasing patients' blood pressure.

4. Increase public awareness about hypertension and the major role of evidence based lifestyle in preventing and reducing complications of this silent disease.

5. Highlight the positive role of self-efficacy as it plays an important role to take steps for making changes in lifestyle and learning new skills to cope with the disease process. 


\section{Further study:}

Develop an educational program for studying the effect of evidence-based lifestyle guidelines on self-efficacy among hypertension patients.

\section{REFERENCES:}

Abd El-Hay ,S., \& El Mezayen ,S.( 2015). Knowledge and Perceptions Related to Hypertension, Lifestyle Behavior Modifications and Challenges That Facing Hypertensive Patients. IOSR Journal of Nursing and Health Science (4), PP 15-26.

Adebayo1, A., Rotkangmwa ,O., and Shalkur ,D. (2015). Hypertension related practices and compliance to anti-hypertensive therapy among hypertensive patients in tertiary health care facilities in Jos, North-Central Nigeria, World Journal of Pharmaceutical Sciences, 3(6): 1151-1158.

Al-daken ,L., and Eshah ,N.(2015). Assessing Publics’ Knowledge about Hypertension in a Community-Dwelling Sample. Journal of Cardiovascular Nursing; 33 (4): $1-8$.

Alaa ,A., Abdelazim, G.A. , Emeash ,A.H. ,Hassan ,D.M and Mustafa, S.B.(2014). Hypertension in Egypt: A Systematic Review. Current Hypertension Reviews, 10, 134-141.

Alharbi, M., Gallagher, R., Kirkness, A., Sibbritt, D., \& Tofler, G. (2014). Longterm outcomes from Healthy Eating and Exercise Lifestyle Program for overweight people with heart disease and diabetes. European Journal of Cardiovascular Nursing, 15(1), 91-99.

Ahmed, B. I., Taha, N. M., Ali, E. E. S., \& Abd EL-Razi, B. G. (2017). Effect of an Educational Program on Knowledge and Self-Efficacy of Patients with Essential Hypertension toward Therapeutic Regimen. Zagazig Nursing Journal, 13(1), 102-116

Al-Jbour ,B., Abu Kamel, A., and Barhoom „H. (2013). Knowledge about Hypertension and Anti-hypertensive Medication Compliance in a Jordanian Community Sample. Journal of Education and Practice; 2013, 4 (24):81-87.

Abdul Rahman A., Wang J.G., Yiu Kwong G.M., Morales A., Sritara P. and Sukmawan R. (2015). Perception of Hypertension Management by Patients and Doctors in Asia: Potential to Improve Blood Pressure Control, Asia Pacific Family Medicine, pp14:2. 
Al Ali,A.A. , Elzubair ,A.G. (2016). Establishing rapport: Physicians' practice and attendees' satisfaction at a Primary Health Care Center, Dammam, Saudi Arabia. J Family Community Med.Jan-Apr; 23(1):12-7. doi: 10.4103/2230-8229.172224.

Behzad, Y., Bastani, F., \& Haghani, H.(2016). Effect of empowerment program with the telephone follow-up (tele-nursing) on self - efficacy in selfcare behaviors in hypertensive older adults]. J Urmia Nurs Midwifery Fac. 2016; 13(11): 1004-15.

Breckenridge, A., Aronson ,J.K., Blaschke, T.F., Hartman, D., Peck, C.C, \&Vrijens, B. (2017). Poor medication adherence in clinical trials: consequences and solutions. Nat Rev Drug Discov

Bunker, J. (2014). Hypertension: Diagnosis assessment and management". Nursing standard, 28(42):50-9. doi: 10.7748/ns.28.42.50.e8682.

Demaio, A. R., Otgontuya, D., de Courten, M., Bygbjerg, I. C., Enkhtuya, P., Oyunbileg, J., \& Meyrowitsch, D. W. (2013). Hypertension and hypertension-related disease in Mongolia; findings of a national knowledge, attitudes and practices study .BMC Public Health, 13(1).

Eckel, R.H., Jakicic, J.M., Ard, J.D., Hubbard, V.S., de Jesus, J.M., Lee, I.M., Lichtenstein, A.H., Loria, C.M., Millen, B.E., Houston Miller, N., Nonas, C.A., Sacks, F.M., Smith, S.C.J., Svetkey, L.P., Wadden, T.W. \& Yanovski, S.Z. (2013). AHA/ACC guideline on lifestyle management to reduce cardiovascular risk: a report of the American College of Cardiology American/Heart Association.

Elaskary, E. (2011). Impact of Health Promotion program on compliance with therapeutic regimen among hypertensive patients in Gaza Strip, Unpublished Doctoral Thesis. Faculty of Nursing, Cairo University.

Ez Elregal, F. (2013). Promoting Health behaviors of Clients with Hypertensive Kidney Disease By Using Health Promotion Model. Unpublished Doctoral Thesis. Faculty of Nursing, Ain Shams University.

Harris, M.F., Lloyd, J., Krastev, Y., Fanaian, M., Gawaine, D., Zwar, N., \& SiawTeng, L. (2014). Routine use of clinical management guidelines in Australian general practice. Australian Journal of Primary Health, 20(1), 41-46. 
Hamed, L.A., Shrief, S.E., Mahdy, A.Y., Arafat, M.A. (2019). Measure Outcomes of Patients' Instructions about Modifiable Risk Factors for Hypertensive Patients on Their Attitude and Lipid Profile. American Journal of Nursing Research, Vol. 7, No. 4, 445-452.

Hu, H., Li, G., \&Arao, T.( 2013). Validation of a Chinese version of the selfefficacy for managing chronic disease 6-item scale in patients with hypertension in primary care. Hindawi Publishing Corporation ISRN Public Health. Vol., Article ID 298986, 6 Pp.

Hjornholm, U., Aamodt, M., Larstorp, A.C., Fadl Elmula, M., Hoieggen, A., Andersen, M.H. \&Kjeldsen, S.E.(2018). Directly Observed Therapy in Hypertension (DOT-HTN). Cham, Switzerland: Springer International Publishing AG; 2018.

Ibrahim ,M. (2013). Problem of Hypertension in Egypt, The Egyptian Heart Journal, 2013, 65(3) PP 233-234, Available at:http://www.egyptheartjournal.com/ article, Accessed on January, 6/2015.

Jarelnape, A. (2016). The Effect of Health Educational Program on Patients' Knowledge About Hypertension and Its' Management (In Sudan - White Nile State). Published Doctorate Thesis. Faculty of Graduate Studies and Scientific Research. The National Ribat University.

Khosravizade , A., Hassanzadeh, A ., and Mostafavi, F.( 2015). The Impact of SelfEfficacy Education on Self- Care Behaviors of Low Salt and Weight Setting Diets in Hypertensive Women Covered by Health-Care Centers of Dehaghan in 2013. J Pak Med Assoc; 65 (5): 506- 511.

Kim, Y., \& Kong, K. A. (2015). Do Hypertensive Individuals Who Are Aware of Their Disease Follow Lifestyle Recommendations Better than Those Who Are Not Aware? PLOS ONE, 10(8), e0136858.

Kofi, J. o. (2011). Prevention and Management of Hypertension: A study on knowledge and attitudes of women of childbearing age. Unpublished Doctoral Thesis , Central Strobothnia University Of Applied Sciences.

Lauffenburger, J.C., Shrank, W.H., Bitton, A., Franklin, J.M., Glynn, R.J., Krumme, A.A., Matlin, O.S., Pezalla, E.J., Spettell, C.M., Brill, G.,\& Choudhry, N.K. (2017). Association between patient-centered medical homes and adherence to chronic disease medications: a cohort study. Ann Intern Med. 2017; 166: 81-88. 
Lauffenburger, J.C, Landon, J.E., \& Fischer, M.A. (2017) .Effect of combination therapy on adherence among US patients initiating therapy for hypertension: a cohort study. J Gen Intern Med. 2017; 32: 619-625.

Mahajan, H., Kazi ,Y., Sharma ,B., Velhal ,G. (2012). Assessment of KAP, Risk Factors and Associated Co-Morbidities in Hypertensive Patients. J Dental Med Sci. 1(2):06-14.

Mersal, F., \& Mersal, N. ( 2015). Effect of Evidence Based Lifestyle Guidelines on Self Efficacy of Patients with Hypertension, Int. J. Curr. Microbiol. App. Sci, , 4(3)Pp 244-263.

Mankan, T., Erci, B., Bahçecioğlu Turan, G., \& Aktürk, Ü. (2017). Turkish validity and reliability of the Diabetes Self-Efficacy Scale. International Journal of Nursing Sciences, 4(3), 239-243. doi:10.1016/j.ijnss. 05.001.

Mularcik, K.(2010). Self-Efficacy toward Health Behaviors to Improve Blood Pressure in Patients who Receive Care Network. Degree of Master of Science in the Graduate School of the Ohio State University, 6-62.

Sarki, A. M., Nduka, C. U., Stranges, S., Kandala, N.B., \& Uthman, O. A. (2015). Prevalence of Hypertension in Low-and Middle-Income Countries. Medicine, 94(50), e1959. doi:10.1097/md.0000000000001959

Sabouhi, F., Babaee, S. Naji, H. and Zadeh, A. (2011). Knowledge, awareness, attitudes and practice about hypertension in hypertensive patients referring to public health care centers in Khoor \& Biabanak. Iran J Nurs Midwifery Res. Winter; 16(1).

Sanders, J.P., Loveday , A., Pearson „N., Edwardson, C., Yates ,T., Biddle, S.J., \&Esliger DW. (2016). Devices for Self-Monitoring Sedentary Time or Physical Activity: A Scoping Review J Med Internet Res;18(5):e90.

Schwarzer R \& Jerusalem M. (1995). Generalized self-efficacy scale. Measures in health psychology user's portfolio. Causal and control belief -NELSON; Windsor, England 1995: Pp .35-37.

Schiffrin, E.L., Campbell, N.R, Feldman, R.D., Kaczorowski, J., Lewanczuk, R., Padwal ,R. \& Tobe, S.W.(2016) . Hypertension in Canada: past, present, and future. Ann Glob Health. 2016; 82: 288-299. 
Somayeh, K., Mohsen ,S. \& Maryam, E.(2016). Comparing the effects of two methods of self-monitoring and telenursing on the blood pressure of patients with hypertension International Journal of Medical Research \& Health Sciences, 2016, 5, 7S: 213-222.

Stoutenberg, M., Stanzilis, K., \& Falcon, A. (2014). Translation of Lifestyle Modification Programs Focused on Physical Activity and Dietary Habits Delivered in Community Settings. International Journal of Behavioral Medicine, 22(3), 312-327.

Subramanian M., Soudarssanane R, Jayalakshmy D, Thiruselvakumar D, Navasakthi, Ajit Sahai, and Saptharishi L.G.(2011). Non-pharmacological Interventions in Hypertension: A Community-based Cross-over Randomized Controlled Trial, Department of Preventive and Social Medicine, Jawaharlal Institute of Postgraduate Medical Education and Research. 36(3).

Varaei, S., Salsali, M., Cheraghi, M., Tehrani, M., \& Heshmat, R. (2013). Education and implementing evidence-based nursing practice for diabetic patients. Iranian Journal of Nursing \& Midwifery Research, 18(3), 251-2

Warren-Findlow, J.,Seymour, R.B., \& Brunner,-Huber, L.R. (2012). The association between self-efficacy and hypertension self-care activities among African American adults. Journal of Community Health, 37, 15-24. doi:10.1017/s10900-011-9410-6.

World Health Organization. (2015). A global brief on hypertension Available at: http:/www.who.int/ cardio-vascular_diseases/publications/global_brief_hypertension/en.

Zungu, L.,\& Djumbe, F.R. (2013). Knowledge and lifestyle practices of hypertensive patients attending a primary health care clinic in Botswana. Published 2013:African Journal for Physical, Health Education, Recreation and Dance. 


\section{تأثثر المبادئ الارشادية لنمط الحياة القائم على الادلة على الكفاءة الذاتية على مرضى ارتفاع ضغط} الددم

شيماء على الوصيف1 ،جهاد محمد ابو المعاطى2 ، رضا ابر اهيم الموافى ، ماجدة على محمد3,4

بكالوريوس تمريض 1 ، استاذ بقم تعريض صحة الاسرة والمجتمع 2, استاذ مساعد بقسم تصريض صحة الاسرة

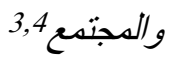

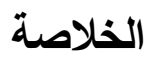

ارتفاع ضغط الدم مرض مزمن يصيب الملايين ويسبب ملايين المضاعفات كل عام في جميع أنحاء العالم. بحتاج الأشخاص المصابون بارتفاع ضغط الدم إلى إجراء العديد من التعديلات على نمط الحياة ، ليس فقط لعلاج ارتفاع ضغط الدم ولكن أيضًا للوقاية من الأمراض المزمنة الأخرى ذات الصلة. الهاف: تقييم تأثير إرشادات أسلوب الحياة القائمة على الأللة على الكفاءة الذاتية بين مرضى ارتفاع ضغط الدم. الموضوع والطريقة: تم استخدام تصميم شبه التهريه تجريبي لإجراء الدراسة. تم تحديد عينة هادفة من 341 مريضًا يعانون من ارتفاع ضغط الدم من ستة مر اكز رعاية

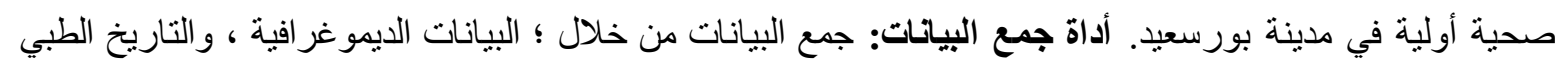
للمريض ، وورقة تقييم المعرفة ، ومقياس أنشطة الرعاية الذاتية لارتفاع ضغط الدم ، ومقياس الكفاءة الذاتية. النتائج:

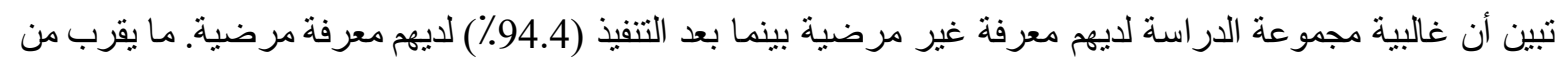

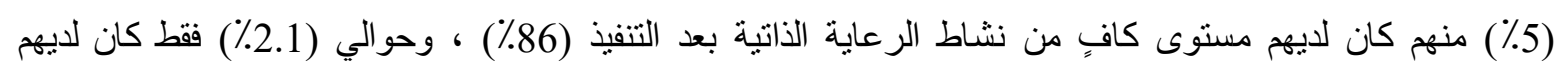
مستوى كافٍ من الكفاءة الذاتبة قبل نطبيق المبادئ الارشادية اما بعد التنفيذ اصبح (97.9٪). الخلاصة: كان لدى معظم مرضى ارتفاع ضغط الدم الخاضعين للار اسة معرفة غير مرضية ، والالتزام بأنشطة الرعاية الذاتية والكفاءة الذاتية

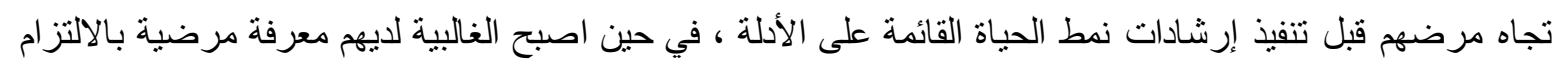

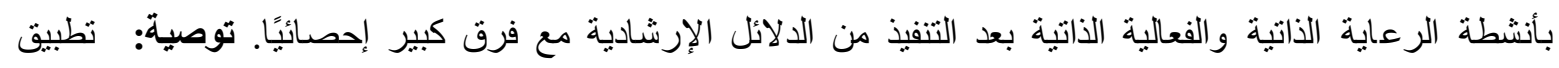

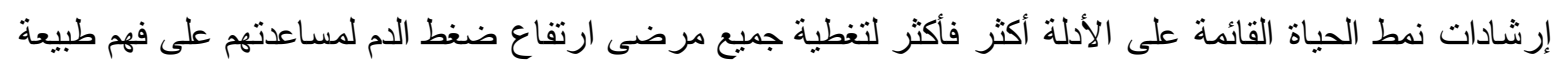
مرضهم المزمن ومحاولة التكيف دون مضاعفات.

الكلمات المرشدة: إرشادات نمط الحياة المبنية على الأدلة ، ارتفاع ضغط الدم ، نشاط الرعاية الذاتية والفعالية الذاتية 